\author{
Agnieszka Więckiewicz \\ Wydział Polonistyki \\ Uniwersytet Warszawski \\ agnieszka.wieckiewicz@gmail.com
}

\title{
Wobec krzywdzących słów. Kilka uwag o niezmiennych mechanizmach mowy nienawiści
}

Niezwykle powszechne w ostatnich latach zjawisko hejtu wymaga spojrzenia syntetyzującego różne perspektywy badawcze: namysłu wykorzystującego narzędzia interdyscyplinarne. Nie wystarczy więc pochylić się nad problemem hejtowania od strony jedynie prawnej (próba definicji hejtu, która odróżniłaby go przede wszystkim od mowy nienawiści), socjologicznej (jak hejt wpływa na społeczeństwo, jakie społeczne uwarunkowania go kształtują), językoznawczej (czym jest hejt i jakimi narzędziami językowymi się posługuje) czy psychologicznej (kim jest hejter?). $\mathrm{W}$ artykule tym chciałabym sięgnąć do poprzedzającej hejt koncepcji mowy nienawiści oraz zaproponować syntezę kilku podejść przedstawionych w klasycznych tekstach omawiających to zjawisko, wykorzystując również perspektywy, które w połączeniu z nimi umożliwią ujrzenie omawianego problemu w szerszym świetle. Nie chcąc ograniczać się tylko do jednego z ujęć będę starała się wskazać na różne konteksty, które bezpośrednio związane są z hejtem.

Definicja złożonego i niejednorodnego zjawiska rozumianego pod pojęciem „hejtu” jest niezwykle trudna do jednoznacznego ustalenia. Instynktownie wyczuwalna różnica między mową nienawiści, hejtem a niebezpieczną mową nie wystarczy do tego, żeby wyznaczyć twarde granice między pojęciami. Podczas gdy niebezpieczna mowa (ang. dangerous speech), obejmująca zachęcanie do podjęcia 
fizycznej przemocy wobec obrażanych, może zostać określona jako radykalniejsza wersja mowy nienawiści, hejt można by wstępnie określić jako „lżejszą” jej formę, która może, ale nie musi się w nią przeradzać, a także rodzaj szeroko pojętej krzywdzącej wypowiedzi, która nie wykorzystuje jednak z góry założonej ideologii, będącej czynnikiem konstytuującym mowę nienawiści.

W moim przekonaniu definicję hejtu powinien poprzedzać namysł nad źródłami i szerokością zjawiska samego hejtowania: głównie kojarzony z cyberprzestrzenią hejt nie musi się do niej ograniczać - w omawiany problem wpisują się również obraźliwe napisy w przestrzeni miejskiej. Stawiając pytanie o źródła hejtu, proponuję przyjrzeć się klasycznym XX-wiecznym dziełom traktującym o mowie nienawiści, które podkreślają jej niezmienne mechanizmy, ukazując zarazem najważniejsze schematy wpływające na zjawisko hejtu.

\section{LTI. Nowomowa. Resygnifikacja}

We wstępie spróbuję przybliżyć trzy klasyczne teksty omawiające zjawisko mowy nienawiści. W świetle zestawionych przeze mnie prac trojga XX-wiecznych badaczy: Victora Klemperera, Michała Głowińskiego i Judith Butler, wskażę czynniki, które sprzyjają upowszechnianiu się praktyk obraźliwego komentowania, krzywdzących haseł i rodzeniu się specyficznego języka, który można określićjako mowęnienawiści.

LTI. Notatnik filologa Victora Klemperera stanowi niewyczerpane źródło wiedzy o języku Trzeciej Rzeszy (Klemperer 2014). Jest to dzieło niezwykle złożone - zawiera językoznawcze, kulturoznawcze i historycznoliterackie uwagi na temat mowy nienawiści, obejmując okres od wczesnych lat trzydziestych do końca drugiej wojny światowej. Dla Klemperera mowa jest przede wszystkim działaniem: aktem stwarzającym rzeczywistość i ustanawiającym możliwe pola wypowiedzi. Mówiąc inaczej, spełnia ona funkcje podobne do zaklęcia, które jest zawsze zapośredniczone społecznie. Bronisław Malinowski, który już w latach trzydziestych określał słowo jako akt, następująco opisał jego magiczną funkcję:

Istnieje przekonanie, iż pewne słowa mają potencjalną moc wywoływania działań. Wypowiesz słowa przysięgi lub złożysz podpis i może okazać się, że na całe życie związałeś się z zakonem, kobietą lub więzieniem. Wypowiesz inne słowo i miliony ludzi czują się szczęśliwe, tak jak to się dzieje, gdy Ojciec Święty błogosławi wierzących. Ludzie postawią wszystko na jedną kartę, zaryzykują swoje życie i majątek, wezmą udział w wojnie lub niebezpiecznej wyprawie, bo wypowiedziano kilka słów. (Malinowski 1987: 105) 
Podkreślona przez polskiego antropologa siła performatywu, który opierając się na zawierzeniu ludzi w określone słowo, zmienia rzeczywistość, ukazana została przez Klemperera w odniesieniu do systemu totalitarnego jako mechaniczna i nieświadoma struktura kształtująca myśli i wszelkie zachowania. Już na pierwszych stronach LTI oddziaływanie systemu Trzeciej Rzeszy na społeczeństwo niemiecki filolog opisuje następująco:

Narodowy socjalizm wślizgiwał się w ciało i w krew tłumu pojedynczymi słowami, zwrotami, formami zdań, które narzucał przez milionkrotne ich powtarzanie i które były przejmowane mechanicznie i nieświadomie. (Klemperer 2014: 21)

Wytwarzając rzeczywistość, dyskurs Trzeciej Rzeszy obejmował i kształtował kontekst słowa, czyli wszelkie punkty odniesienia, sprawnie stosując mechanizmy propagandy (Burke 1983). W efekcie rzeczywistość społeczna kształtowała się pod wpływem utrwalanych obrazów i haseł, które przedostawały się do wszystkich sfer życia, zaburzając granice między tym co prywatne, a tym co publiczne.

Klemperer ujmuje język Trzeciej Rzeszy jako truciznę, wobec której nikt nie pozostaje obojętny. To właśnie owa wszechobecność LTI (Lingua Tertii Imperii) stanowi o tworzeniu się nieświadomych połączeń wyznaczających nowe (niebezpieczne) płaszczyzny myślenia. Język jest w takim ujęciu narzędziem, które odpowiada na określone społeczne potrzeby (Klemperer 2014: 15-22).

Najważniejszą kategorią dyskursu Trzeciej Rzeszy, jak podkreślał Klemperer, są przesunięcia semantyczne - termin pierwotnie oznaczający coś innego, zmienia swoje znaczenie, często na przeciwne. Przykładem może być słowo „fanatyzm”, które w okresie rządów Hitlera przybrało pozytywne znaczenie, mając uprzednio wymowę zabarwioną jednoznacznie pejoratywnie (Klemperer 2014: 62-66). Podobnie zachowywało się pojęcie „patriotyzm”, podatne na manipulacje również w dzisiejszym polskim kontekście. Język propagandy, którego głównym celem jest ukształtowanie społecznej wyobraźni, wiąże się ściśle z mową nienawiści - mechanizmy obu wymienionych języków mieszają się ze sobą, pozostając w praktyce nierozłączne.

Możliwe, że najważniejszym wnioskiem płynącym z lektury LTI jest ukazanie języka nienawiści jako narzędzia, którego nie można porzucić w dowolnym momencie. Wpływ dyskursu, który jest zarazem trucizną, sięga znacznie głębiej, niż widać:

Ale język nie tylko składa słowa i myśli za mnie: kieruje również moim uczuciem, steruje całą moją duchową istotą - tym bardziej, im bardziej bezrefleksyjnie, nieświadomie mu się poddaję. A jeśli wysoka mowa powstała z elementów trujących albo jeśli zrobiono z niej nosiciela trucizny? Słowa mogą być jak maleńkie dawki jadu: połyka się je niepostrzeżenie, wydają się nie mieć żadnego skutku, a jednak po pewnym czasie 
występuje trujące działanie. Jeśli ktoś dostatecznie długo coś bohaterskiego i cnotliwego nazywa fanatycznym, to wreszcie rzeczywiście uwierzy, że fanatyk to cnotliwy bohater i że bez fanatyzmu nie można być bohaterem. (Klemperer 2014: 21)

Ten krótki fragment streszcza to, na co wskazywałam już wcześniej, zarazem pozwalając na wykazanie analogii z pewnymi mechanizmami kierującymi hejtem. Język, za pomocą którego określa się, piętnuje bądź komentuje wybrane grupy i jednocześnie je stwarza, pozostaje w ścisłej korespondencji z funkcjonującym powszechnie przekonaniem o tej grupie. Mówiąc inaczej, gdyby kontekst społeczny był inny, to możliwe, że grupy, które w tej chwili są obrażane, pozostawałyby poza polem ataku, podobnie jak samo zjawisko hejtu mogłoby nie zyskać takiej popularności.

Podejmując próbę ponownego zdefiniowania języka hejtu i odróżnienia go od mowy nienawiści, proponuję ujęcie tej drugiej jako kodu kulturowego, który wybierając pewne punkty odniesienia, kształtuje całą rzeczywistość, natomiast języka hejtu - jako zróżnicowanego pod względem obraźliwości dyskursu, który będąc ściśle powiązany z kodem kulturowym i rzeczywistością społeczną, odwołuje się do ukształtowanych wcześniej wyobrażeń społecznych, jednocześnie je przetwarzając i utrwalając.

Na gruncie polskich badań nad społecznymi możliwościami języka zjawiskiem propagandy zajmował się Michał Głowiński, który opisał mechanizmy języka okresu PRL-u (Głowiński 2009). W jego ujęciu nowomowa, podobnie jak LTI, „oblepia” mówiącego, kształtując jego myślenie i obraz rzeczywistości. Aspirując do uniwersalności, skazuje ona nieużywane słowa na nieistnienie - wyznacza nieprzekraczalne granice, które są efektem i ekspresją postaw normatywnych. Nowomowa jest zawsze wartościowaniem: nigdy nie informuje o stanie rzeczy, lecz zawsze jest już interpretacją. Dzięki sprawnemu przechwytywaniu i udosłownianiu metafor, stwarza spójne obrazy rzeczywistości, które podobnie jak mowa nienawiści w ujęciu Klemperera konstytuują się wokół ustalonego wyobrażenia wroga.

Odwrotną stroną zjawiska mowy nienawiści jest zagadnienie możliwości obrony przed „krzywdzącymi słowami”. Głowiński proponuje w tym kontekście strategię parodii, Judith Butler - metodę polegająca na przechwytywaniu krzywdzącego języka i resygnifikowaniu wykorzystywanych w nim pojęć.

Na elastyczność języka, dzięki której zmiana znaczenia jest możliwa, wskazywała Butler w Walczacych słowach (Butler 2010). Ujęcie amerykańskiej filozofki różni się od dwóch omówionych wcześniej ze względu na przedmiot badań - w odniesieniu do zagadnienia mowy nienawiści zwróciła ona przede wszystkim uwagę na mechanizmy rządzące dyskursem politycznym. Odwołując się do Austinowskiego ujęcia języka, rozszerzyła pojęcie performatywu, który powiązała 
z mechanizmami nazywania (wzywania/wyzywania) określonych grup, które formują się i kształtują w obrębie pola wyznaczonego dla nich przez krzywdzącą nazwę. Podobnie jak Klemperer i Głowiński dowodziła, że język w performatywny sposób kształtuje rzeczywistość, umożliwiając jednym podmiotowościom zaistnienie, a inne spychając do sfery braku wypowiadalności. Butler podkreślała problem bycia i pozycji osoby wykluczonej wobec mowy nienawiści i wskazywała na szansę przezwyciężenia obraźliwego działania słów poprzez zmianę ich znaczenia przez grupy nazwane krzywdząco. Nie wszystkie wyrazy - pisze Butler - poddają się resygnifikacji, ale te, które mogą, należy przechwycić. Buntownicza mowa sprzeciwia się dominującemu (i zarazem krzywdzącemu) użyciu słowa, jest także konieczna do przeprowadzenia i zaistnienia resygnifikacji, przeciwko której działa cenzura (podejmowaną nawet w szczytnym celu wyjęcia spod powszechnego użycia obraźliwych wyzwisk). Butler w swoim ujęciu podmiotowości wzywanych do bycia takimi, jakimi określa się je za pomocą krzywdzącej nazwy, wskazała na sprawczy potencjał i charakter Innego, który nie musi być bierny. Jedyną możliwością obrony nie jest wymazanie czy odepchniecie obraźliwych słów, ale ich wykorzystanie - odebranie im ich krzywdzącego działania poprzez nieprzyjmowanie zamierzonej przez nadawcę postawy emocjonalnej.

Przyjęcie imienia, przez które zostało się wezwanym, nie jest prostym poddaniem się istniejącemu autorytetowi, ponieważ w momencie przyjęcia imię jest już wyabstrahowane $\mathrm{z}$ dotychczasowego kontekstu i włączone w pracę samodefinicji. Raniące słowo staje się narzędziem oporu w nowym rozmieszczeniu sił, niszczącym terytorium, na którym dotychczas działało. Takie przegrupowanie sił oznacza wypowiadanie słów bez polegania na wcześniejszej autoryzacji oraz wystawienie na ryzyko pewności języka życia, poczucia własnego miejsca w języku, tego, że słowa będą robiły to, co się mówi. Ryzyko to jednak dotyka nas już w momencie, w którym krzywdzący język stawia pod znakiem zapytania przetrwanie tego, do kogo się zwraca. Buntownicza mowa staje się niezbędną odpowiedzią na krzywdzący język - to ryzyko podjęte w reakcji na ryzyko, na które zostało się wystawionym, powtórzenie w języku zdolne wymusić jego zmianę. (Butler 2014: 188)

Mechanizm rządzący resygnifikacją ujawnia $\mathrm{w}$ ujęciu Butler ambiwalencję kryjącą się w języku, w którym przesunięcia semantyczne mogą służyć emancypacji wykluczonej grupy, jej wejściu w pole wypowiadalności, będąc jednocześnie skutecznym narzędziem do manipulacji i kształtowania wyobraźni społecznej wokół postaci wroga.

Walkę z hejtem przeprowadza się na różnych płaszczyznach. Jednak aby wyraźniej podkreślić istotną subwersywność kryjącą się w propozycji Butler, chciałabym zestawić $\mathrm{z}$ ową propozycją próby odpowiedzi na obraźliwą mowę, hasła, komentarze dokonywane poprzez zgłaszanie ich do jak najszybszego usunięcia 
bądź bezpośrednie wymazanie nienawistnych napisów (na przykład z przestrzeni publicznej). W świetle jej koncepcji wymazywanie nie rozbija dotychczasowego znaczenia słowa, za to - przeciwnie - może je utrwalać poprzez zgodę na jego znaczenie, potwierdzając zarazem niemo zgodność skonstruowanej przez nadawcę nazwy z grupą, którą określa. Co więcej, wymazanie umacnia i zespala nazwanych z nazwą, którzy zostali niejako powołani do życia w zderzeniu z jej krzywdzącym działaniem. W odpowiedzi na obraźliwe słowo, przyjmując oczekiwaną i zamierzoną przez nadawcę postawę emocjonalną, przyjmuje się tym samym zaprojektowane znaczenie słowa.

\section{Performowanie słowem}

Hejtowanie można rozumieć jako pewną formę wypowiedzi (ustnej bądź pisemnej), która spełnia rolę specyficznego medium komunikacji społecznej, często wytwarzając grupy sprzeciwiające się określonemu zachowaniu, rzeczy, osobie itp. W dobie kultury internetu - będącej modelowym przykładem kultury konwergentnej, w której wyobraźnia kształtowana jest w wyniku swoistego zlepiania, mieszania i przetwarzania informacji uzyskanych z różnych źródeł - krzywdzące wypowiedzi czy komentarze powstają za sprawą stereotypowych wyobrażeń utwierdzanych poprzez rozmaite media. Kultura internetu idealnie nadaje się do szybkiego przetrawiania i utrwalania klisz językowych, zacierając dodatkowo granice między tym, co prywatne, a co publiczne (Jenkins 2007: 15-17). Wytwarzanie konkretnych grup polega w niej w dużej mierze na wyznaczeniu i przypisaniu im konkretnych cech czy zachowań, które będzie można później piętnować. Obraźliwe wypowiedzi często odwołują się do cech osobistych albo takich, których nie można zmienić, mówiąc inaczej: takich, przed którymi nie można się obronić. Dobór naznaczonych grup będących obiektem obraźliwych komentarzy sprawia wrażenie przypadkowego - przedmiotem agresji słownej może być zarówno osoba o innym kolorze skóry, orientacji seksualnej, płci, poglądach politycznych, jak i o odmiennej od (arbitralnie) ustalonej normy wadze.

Mówiąc o hejcie, pojawiającym się w formie obraźliwego komentarza, jako o akcie komunikacji, trzeba jednak dodać, że jest to akt niepełny: nie wiadomo jednoznacznie, kto jest nadawcą krzywdzącej wypowiedzi - konkretna osoba czy grupa osób o określonych przekonaniach, które mają się unaocznić za sprawą komentarza? Przestrzeń internetu zwiększa dodatkowo poczucie bezkarności w wydawaniu sądów, zachęcając tym samym użytkowników do wypowiedzi, których nie odważyliby się powołać do życia w „realnym” świecie. 


\section{Slogan, cliché. Trwałość obrazu}

Obraźliwe komentarze, hasła i napisy korzystają ze wspólnego tworzywa językowego, kreując specyficzny obraz obrażanego i obrażającego, który utrwala się poprzez nieustanne powielanie gotowych wyrażeń lub haseł (sloganów). Zjawisko hejtu, co pragnę wykazać, jest ściśle powiązane z owymi zbiorowymi tożsamościami, które konstytuują się za sprawą powielanych stereotypów i populistycznych perswazji (Laclau 2009).

Klisza językowa opiera się na kilku prostych mechanizmach: poprzez sprowadzenie pojęć do jednego mianownika ułatwia zapamiętanie wytworzonego intencjonalnie obrazu, dzięki zmianie sensu treści, znaczącej wcześniej coś innego - zafałszowuje opisywany stan rzeczy, którego właściwy charakter maskuje. W wyniku tak, a nie inaczej definiowanych pojęć stosowanie klisz umożliwia manipulowanie polityczną rzeczywistością (Stern 1980: 286-287). Najgroźniejsza pułapka, która łączy klisze z mową nienawiści, to wrażenie, że wykorzystywany przez nie język opisuje rzeczywistość, a nie ją zmienia.

Mechanizmy kształtujące klisze językowe mogą stać się pomocne w opisie języka hejtu. Język, którym posługuje się hejter, nie tylko nie opisuje rzeczywistości, ale opiera się na mechanizmie emocjonalizacji odbioru, spełniając tym samym warunek bezrefleksyjnej percepcji - czynnika uskuteczniającego oddziaływanie stereotypów. Bycie obrażonym, pokrzywdzonym otwiera problematyczną zależność pomiędzy hejtującym a zhejtowanym - relację, którą ciężko przezwyciężyć.

Jak wiadomo, slogany pojawiające się przede wszystkim w dyskursie politycznym i reklamach mogą przybierać formy zarówno bardziej jawne, jak i utajone. Podobnie dzieje się z mową nienawiści i hejtem: granice wyznaczane, by określić punkt, w którym dana wypowiedź może zostać uznana za mowę nienawiści, zależą bezpośrednio od systemu politycznego wpływającego na kształt wrażliwości społecznej. Problem z przyzwoleniem na mowę nienawiści czy hejt może wiązać się z brakiem uwrażliwienia grup, które nie utożsamiają się z obrażanymi. Ponadto, jeżeli w powszechnym przeświadczeniu zachowanie bądź orientacja seksualna piętnowanej osoby są uznawane za pewne odchylenie od normy, to jednostki utożsamiające się $\mathrm{z}$ tą grupą będą miały większe szanse na spotkanie się z brakiem wsparcia ze strony innych w obliczu zhejtowania. Słów odgrywających rolę swoistego tabu, które określają wybrane grupy (słów, do których nikt nie chce się przyznać: żyd, imigrant, gej, lesbijka, feministka itp.), w powszechnym użyciu jest bardzo wiele i to właśnie one często pojawiają się jako „obelgi” używane bez względu na kontekst w krzywdzących komentarzach czy wypowiedziach. 


\section{Podsumowanie}

Zestawione przeze mnie ujęcia trzech różnych koncepcji dotyczących mowy nienawiści miało na celu wykazanie niezmienności jej mechanizmów, które wpływają na kształt i formę hejtu - niebędącego zjawiskiem ani nowym, ani oderwanym od czynników warunkujących mowę nienawiści, dyskurs polityczny czy niebezpieczną mowę. Obecnie, za sprawą licznych mediów i kanałów komunikacji (telewizja, internet, reklama) reprodukujących schematy i obrazy mające opisywać rzeczywistość nie sposób jest mówić o niezależnym czy obiektywnym źródle informacji, które nie preparowałoby zaprojektowanych ideologicznie płaszczyzn myśli i wyobraźni społecznej. Hejt, ujęty jako wszelkie krzywdzące i obraźliwe komentarze, hasła, wypowiedzi czy zachowania, musi zostać umieszczony w tym samym polu co pozostałe omawiane powyżej zjawiska, ponieważ podobnie jak język propagandy czy mowa nienawiści może służyć manipulacji i utwierdzaniu struktury społecznej. Hejt kształtuje się bowiem wokół skonstruowanego językowego obrazu wroga, tego, który jest inny i obcy. Wytwarza wspólnotę i, podobnie jak język propagandy, określa jej ramy: naród niemiecki - Żydzi, państwa socjalistyczne - Zachód, „prawdziwi Polacy” - uchodźcy albo lewica.

Krzywdzącym słowem kieruje się w taki sposób, aby w wyniku cyrkulacji stereotypowych obrazów między różnymi mediami utrwalało się ono, zacierając granicę pomiędzy tym, co prywatne a publiczne. Cyberprzestrzeń umożliwiająca specyficzną formę zaistnienia (wypowiedzenia się) przejmuje schematy języka wytworzone w dyskursie publicznym i kształtuje formę i treść możliwych wypowiedzi. Konwergentny charakter internetu wzmaga utrwalanie stereotypowych skojarzeń poprzez mechanizację myślenia.

Pytając o to, kim jest nadawca komunikatu, kim jest hejter, wskazuje się zazwyczaj na problem anonimowości w przestrzeni internetu. Ważniejszym jednak pytaniem, na które trzeba odpowiedzieć, zanim spróbuje się określić portret psychologiczny hejtera, jest w moim przekonaniu pytanie o obraz, który wynika z obraźliwych słów - to on musi najpierw zostać zdekodowany i rozbity, ponieważ to on jest zwierciadłem odbijającym struktury społeczne warunkujące mechanizmy hejtu. 


\section{Bibliografia}

Barthes Roland (2008), Mitologie, przeł. A. Dziadek, Wydawnictwo Aletheia, Warszawa.

Burke Kenneth (1983), Retoryka „Mein Kampf”, przeł. M. Szpakowska [w:] Nowa krytyka. Antologia, wyb. H. Krzeczowski, oprac. Z. Łapiński, PIW, Warszawa. Butler Judith (2010), Walczace słowa. Mowa nienawiści i polityka performatywu, przeł. A. Ostolski, Wydawnictwo Krytyki Politycznej, Warszawa.

Głowiński Michał (2009), Nowomowa i ciagi dalsze. Szkice dawne i nowe, Universitas, Kraków.

Jenkins Henry (2007), Kultura konwergencji, przeł. M. Bernatowicz, M. Filiciak, Wydawnictwo Akademickie i Profesjonalne, Warszawa.

Klemperer Victor (2014), LTI. Notatnik filologa, przeł. J. Zychowicz, Wydawnictwo Aletheia, Warszawa.

Laclau Ernesto (2009), Rozum populistyczny, przeł. T. Szkudlarek, Wydawnictwo Naukowe Dolnośląskiej Szkoły Wyższej, Wrocław.

Lister Martin (2009), Nowe media. Wprowadzenie, przeł. M. Lorek, A. Sadza, K. Sawicka, Wydawnictwo UJ, Kraków.

Malinowski Bronisław (1987), Ogrody koralowe i ich magia. Studium metod upraw ziemi oraz obrzędów towarzyszących rolnictwu na Wyspach Trobrianda. Język magii i rolnictwa, przeł. B. Leś, red. nauk. A. K. Paluch, PWN, Warszawa.

Marcuse Herbert (1991), Człowiek jednowymiarowy. Badania nad ideologia rozwiniętego społeczeństwa przemysłowego, przeł. A. Chwieśko, oprac. W. Gromczyński, PWN, Warszawa.

Popper Karl (1999), Opinia publiczna a zasady liberalizmu [w:] tegoż, Droga do wiedzy. Domysty i refutacje, przeł. S. Amsterdamski, PWN, Warszawa.

Puzynina Jadwiga (1997), O manipulacji językowej, O dyskursie oceniajacym i dyrektywnym [w:] tejże, Słowo - wartość - kultura, Towarzystwo Naukowe KUL, Lublin.

Stern Josef Peter (1980), Manipulacja za pośrednictwem „cliche”, przeł. M. Łukasiewicz [w:] Język i społeczeństwo, M. Głowiński (red.), Wydawnictwo Czytelnik, Warszawa. 


\section{Agnieszka Więckiewicz}

\section{Wobec krzywdzących słów. Kilka uwag o niezmiennych mechanizmach mowy nienawiści}

\section{Regarding Injurious Words. A Few Remarks on Immutable Mechanisms of Hate Speech}

Słowa kluczowe: mowa nienawiści, język propagandy, stereotypy, mniejszości, klisze Key words: hate speech, propaganda speech, stereotypes, minority groups, clichés

\section{Streszczenie}

W artykule przedstawiono koncepcję odróżnienia hejtu od języka propagandy i mowy nienawiści poprzez wskazanie na łączące je bezpośrednio relacje. Kolejno, z perspektywy różnych ujęć badawczych, omówione zostały społeczne i językowe uwarunkowania hejtu. Następnie, dzięki zestawieniu trzech klasycznych tekstów dotyczących mowy nienawiści, ukazano niezmienne mechanizmy rządzące zarówno mową nienawiści oraz językiem propagandy, jak i językiem hejtu. W końcowej części artykułu omówione zostały możliwości obrony przed krzywdzącymi komentarzami lub wypowiedziami.

\footnotetext{
Abstract

In the article the author analyzes and interprets mechanisms of hate speech and propaganda speech which have had a great impact on contemporary culture. In order to understand the phenomenon of hate speech fully, the author tries to find the processes and procedures that lead to creation of propaganda speech as well as hate speech in modern society by considering the classic texts which regard the problem of propaganda in the $20^{\text {th }}$ century. The impact of mass media on perception has resulted in constantly repetitive structures of thinking which create stereotypical images.
} 